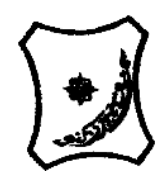

Bayero Journal of Pure and Applied Sciences, 14(1): 38 - 44

Received: January, 2021

Accepted: May, 2021

ISSN $2006-6996$

\title{
IN-VITRO ANTIBACTERIAL ACTIVITY OF CINNAMON BARK EXTRACTS ON CLINICAL MULTI-DRUG RESISTANT (MDR) Staphylococcus aureus, Klebsiella pneumoniae AND Pseudomonas aeruginosa ISOLATES
}

\author{
Idris, F. Z. ${ }^{1}$ and Habibu, U. A. ${ }^{1 *}$ \\ Department of Microbiology, Bayero University, Kano \\ ${ }^{1 *}$ Corresponding author: huabdu.mcb@buk.edu.ng, +2348036924792
}

\section{ABSTRACT}

The present study was conducted to investigate antimicrobial activity of ethanol, dichloromethane and n-hexane extracts of Cinnamomum verum stem bark against Multidrug resistant clinical isolates. $C$. verum bark powder was extracted with ethanol, dichloromethane and hexane respectively using Soxhlet extractor for 6 hrs. at temperature not exceeding the boiling point of the respective solvents. The extracts were further subjected to phytochemical screening as well as antimicrobial tests against clinical isolates of confirmed multi-drug resistant Staphylococcus aureus, Klebsiella pneumoniae and Pseudomonas aeruginosa using agar well diffusion method. Minimum inhibitory concentrations (MICs) and Minimum bactericidal concentrations (MBCs) were also determined. The extracts yield 11.8g, $10.2 \mathrm{~g}$ and $9.0 \mathrm{~g}$ for ethanol, dichloromethane and hexane respectively. The results of phytochemical screening indicated the presence of alkaloids, reducing sugars, saponins, steroids, cardiac glycoside, flavonoid, anthraquinones and tannins in the extracts. The ethanolic extracts showed the highest antimicrobial activity of $12.3 \pm 0.5 \mathrm{~mm}$ against $P$. aeruginosa and $15.3 \pm 1.3 \mathrm{~mm}$ against $K$. pneumoniae at $100 \mathrm{mg} / \mathrm{ml}$ and antibacterial activities of $11.3 \pm 0.5 \mathrm{~mm}$ against $K$. pneumoniae followed by $9.0 \pm 0.4 \mathrm{~mm}$ against Pseudomonas aeruginosa and the least $8.0 \pm 0.0 \mathrm{~mm}$ against Staphylococcus aureus at $20 \mathrm{mg} / \mathrm{ml}$ concentration. While hexane extract of the plant has the highest activity of $9.0 \pm 0.0 \mathrm{~mm}$ against Staphylococcus aureus isolates but less active against the remaining isolates at $20 \mathrm{mg} / \mathrm{ml}$ concentration. Dichloromethane extract was less active against all the MDR isolates. The results showed that the MICs of C. verum ranged from $5-20 \mathrm{mg} / \mathrm{ml}$ while the MBCs ranged from 10-40 $\mathrm{mg} / \mathrm{ml}$. Thus $C$. verum could be used as potential source of antibacterial agents against MDR microbes.

Keywords: Antibacterial activity, Multi-drug resistant, Cinnamomum verum, Extracts

\section{INTRODUCTION}

Since ancient time, plants have been utilized as an important source of medicine as they are a reservoir of essential bioactive compounds with antimicrobial properties (Sofowora et al., 2013). Herbal medicine is the use of plant for medicinal purpose hence it's a plant or plant part valued for its medicinal, aromatic and savory quality (Tapsell et al., 2006). The use of herbal medicine is popular in several local communities in Nigeria as well as other developing countries. Prominent among the reasons is poverty among the populace as well as lack of basic primary health care system (Oke, 2000). Throughout history, there has been a continual battle between humans and the multitude of microorganisms that cause infections and diseases. Thus, the treatment of bacterial infections is increasingly complicated by their ability to develop resistance to antimicrobial agents. Cinnamomum verum is a small classic tree, belonging to the family Lauraceae, native to Sri Lanka and South India. The flowers have a greenish color and have a distinct odor and arranged in panicles (Dylan et al., 2009). The fruit is a purple one-centimeter berry containing a single seed. Its flavor is due to an aromatic essential oil which makes up 0.5 to $1 \%$ of its composition. The oil extract of Cinnamon aids in the preservation of certain foods through its antimicrobial properties (Meena et al., 2012; Khandelwal, 2008). Previous studies have shown that Cinnamon can prevent microorganism-induced food spoilage (De La Torre et al., 2015). Antibacterial activities particularly against Bacillus subtilis, Staphylococcus aureus, Escherichia coli, Salmonella typhi, Klebsiella and Pseudomonas 
BAJOPAS Volume 14 Number 1, June, 2021 aeruginosa have been demonstrated (Miyashita and Sadzuka, 2013; Sheng and Zhu, 2014).

The emergence of infections caused by drugresistant bacteria is a serious and growing global health concern. Therefore, significant efforts are being made in the development of new antimicrobial compounds with improved efficacy (Prestinachi et al., 2015; Manaa et al., 2015; Alabi et al., 2013). However, despite these efforts, an increasing number of multidrug- resistant bacteria including methicillin-resistant Staphylococcus aureus (MRSA), Staphylococcus aureus, Klebsiella pneumoniae and Pseudomonas aeroginosa are being reported continuously (Alabi et al., 2013; Nurjadi et al., 2015; Klein et al., 2013). The aim of this research was to determine antimicrobial activity of Cinnamomum verum bark extracts using different solvents against some MDR isolates with the aim of finding possible alternative treatment(s) to infections caused by such organisms.

\section{MATERIALS AND METHODS \\ Sample collection and preparation}

Cinnamomum verum used in this study was purchased from kurmi market, Kano metropolis. The plant was identified and authenticated as Cinnamomum verum in the Plant Biology Department, Bayero University, Kano. The purchased sample was cleaned, washed and airdried under the shade. Dried stem bark were ground into fine powder using mortar and pestle in the laboratory and then sieved with 250 micro meter mesh size to obtain very fine powder then stored in a dry and sterile container (John et al., 2003).

\section{Extraction}

Three different solvents with varying polarities were used in order to exploit the varying solubility of the plant constituents as described by (Sarker et al., 2006). The three organic solvents selected were; n-hexane $(70 \%)$, dichloromethane $(70 \%)$ and ethanol (100\%) with low, moderate and high polarities respectively. The extraction of the plant material was conducted using Soxhlet apparatus (Pyrex Company, UK). Exhaustive extraction using Soxhlet extraction procedure was used to extract as many compounds as possible from the plant materials using a method described by Mustafa and Hilal, (2004) and Yusha'u et al. (2010). $100 \mathrm{~g}$ of prepared Cinnamon bark was accurately weighed in to 3 different conical flasks. A $1000 \mathrm{ml}$ of $70 \%$ n-Hexane, $70 \%$ Dichloromethane, $100 \%$ Ethanol and six pieces of anti-bumping granules were added to each flask separately with vigorous shaking for 10 min then left for $48 \mathrm{hrs}$. at room temperature. The crude extracts were filtered and evaporated $\left(45-50{ }^{\circ} \mathrm{C}\right)$ to obtain the respective extracts. The extracts were stored in a refrigerator at $4^{\circ} \mathrm{C}$ until use.

\section{Phytochemical screening}

Various phytochemical tests were carried out on the extracts in order to determine the presence or absence of active secondary metabolites; alkaloids, reducing sugars, saponins, steroids, cardiac glycoside, flavonoid, anthraquinones and tannins following standard techniques (Aiyelaagbe and Osamudiamen, 2009; Ciulci, 1994; Sofowora, 1993; Brain and Turner, 1975). Each test was qualitatively expressed as positive $(+)$ or negative $(-)$ for presence or absence of active secondary metabolites.

\section{Preparation of Stock Solution of Extracts}

Various weight of the crude extracts $(0.5 \mathrm{~g}, 0.4 \mathrm{~g}$, $0.3 \mathrm{~g}, 0.2 \mathrm{~g}$ and $0.1 \mathrm{~g}$ ) were dissolved in $5.0 \mathrm{ml}$ of $20 \% \mathrm{v} / \mathrm{v}$ Dimethyl Sulfoxide (DMSO) separately to obtain the following concentration; $100 \mathrm{mg} / \mathrm{ml}$, $80 \mathrm{mg} / \mathrm{ml}, 60 \mathrm{mg} / \mathrm{ml}, 40 \mathrm{mg} / \mathrm{ml}$ and $20 \mathrm{mg} / \mathrm{ml}$. The concentration were stored at $15^{\circ} \mathrm{C}$ in a sample bottles for further analysis (Kuta et al., 2012).

\section{Test isolates}

The test microorganisms were obtained from the Department of Microbiology and Parasitology, Aminu Kano Teaching Hospital, Kano in 2020. Conventional biochemical tests were used to further identify and confirm the test organisms as Pseudomonas aeruginosa, Klebsiella pneumonia and Staphylococcus aureus. Different media such as Nutrient agar, Nutrient broth, Mannitol Salt Agar (MSA), Mueller Hinton Agar (MHA), Mueller Hinton Broth (MHB) were used for the reconfirmation of the test organisms.

\section{Inoculum Standardization}

Few colonies of confirmed MDR Pseudomonas aeruginosa, Klebsiella pneumonia and Staphylococcus aureus were dispensed in sterile normal saline to match the 0.5 McFarland standard for sensitivity tests as described by CLSI (2012).

\section{Antibacterial susceptibility assay}

This was achieved by agar well diffusion method described by CLSI (2012). Standardized inocula of the confirmed MDR isolates were swabbed onto the surface of prepared and solidified Mueller Hinton Agar in separate Petri-dishes. Using a cork borer, four wells of $6 \mathrm{~mm}$ in diameter were bored in the inoculated Muller Hinton agar. $50 \mu$ of each concentration of the test extracts were delivered into each well using a micropipette. The plates were incubated at $37{ }^{\circ} \mathrm{C}$ for $24 \mathrm{hrs}$. The antibacterial activity of the extracts was determined after the incubation by measuring the mean diameter zones of inhibition produced by each of the extracts against the bacterial isolates and the result was recorded in $\mathrm{mm}$. 
BAJOPAS Volume 14 Number 1, June, 2021 Determination of Minimum Inhibitory Concentration (MIC)

The MIC of the extracts was determined using the method described by (Yusha'u et al., 2010) by diluting the extracts in 2-fold serial dilution starting from $40 \mathrm{mg} / \mathrm{ml}$ to $2.5 \mathrm{mg} / \mathrm{ml}$ with nutrient broth at $1 \%$ concentration in a series of test tubes and to each of the test tubes, $0.5 \mathrm{ml}$ of the test organism was added and incubated at $37^{\circ} \mathrm{C}$ for 24 hrs. Control was prepared by inoculating tubes with test organisms without extract as positive control and another with nutrient broth and the extract without the test organism as the negative control. The tubes were then examined for the presence of turbidity after the incubation period of $24 \mathrm{hrs}$. at $37^{\circ} \mathrm{C}$. The least concentration with no observable bacterial growth when compared with the control was recorded and was considered as the Minimum Inhibitory Concentration (MIC).

Determination of Minimum Bactericidal Concentration (MBC)

The suspension from the minimum inhibitory concentration tubes that showed no growth was inoculated on nutrient agar and was incubated overnight at $37^{\circ} \mathrm{C}$ for $24 \mathrm{hrs}$. After incubation, the concentration that showed no visible growth was considered as the Minimum Bactericidal concentration (MBC). Both MIC and MBC for the test bacteria were determined in duplicate assay and the data were shown as the mean \pm SD.

\section{RESULTS AND DISCUSSION}

Cinnamon verum extracts physical properties (weight and physical appearance) shown in table 1 revealed that the highest yield of Cinnamomum verum extract $11.8 \mathrm{~g}$ was observed in ethanol extract followed by $10.2 \mathrm{~g}$ of dichloromethane extract, while $n$-hexane extract has the least yield of $9.0 \mathrm{~g}$. The Cinnamomum verum ethanol extracts were dark brown in color, powdery in texture with a pungent smell. The dichloromethane extracts were dark brown in color, powdery in texture with a chocking smell while the $n$-hexane extracts were light brown in color, sticky in texture and a pungent smell.

Table 1: Physical properties and yield of C. verum extracts

\begin{tabular}{llllr}
\hline Extract & \multicolumn{3}{c}{ Physical Appearance } & $\begin{array}{l}\text { Weight of } \\
\text { extract (g) }\end{array}$ \\
\cline { 2 - 4 } & Color & Texture & Odor & \\
\hline Ethanol & Dark brown & powdery & pungent & 11.8 \\
Dichloromethane & Dark brown & powdery & chocking & 10.2 \\
n-Hexane & Light brown & sticky & pungent & 9.0 \\
\hline
\end{tabular}

The highest yield of $C$. verum ethanol extract could be associated with its high polarity (polarity index of 4.3) while the least was hexane extract with polarity index of 0.1 . This result is in line with work of Madiha et al., (2017). However, Rezaie et al., (2015) stated that the efficiency of the different extraction solvents strongly depends on the composition of the plant materials.

The results of phytochemical screening of the three extracts revealed the presence of secondary metabolites that includes; alkaloids, reducing sugars, saponins, steroids, tannins, cardiac glycoside, flavonoids and anthraquinones as shown in table 2 . This is consistent with the findings of Mazimba et al., (2015). The secondary metabolites are responsible for antibacterial activities and varies based on solvent extraction.
The results shows variation in the phytochemicals present in the various extracts. Hexane extracts revealed the presence of 7 out of the 8 screened bioactive compounds while ethanol and dichloromethane extracts revealed the presence of 6 and 5 out of the 8 screened bioactive compounds respectively. Saponins was detected in ethanol and $\mathrm{n}$-hexane extracts but undetected in the dichloromethane extracts which might be the reason for greater antibacterial activities recorded in the ethanol and n-hexane extracts. This finding is in agreement with that of. Mujahid et al., (2017). These bioactive compounds have been reported to possess antimicrobial activity (Cowan, 1999) particularly alkaloids and tannins are well documented for antimicrobial activity (Tschehe, 1971; Sofowora et al., (2013). 
BAJOPAS Volume 14 Number 1, June, 2021

Table 2: Phytochemical constituents of $C$. verum extracts

\begin{tabular}{lccccccccr}
\hline & \multicolumn{9}{c}{ Phytochemical components } \\
Extracts & $\mathrm{T}$ & $\mathrm{F}$ & $\mathrm{Aq}$ & $\mathrm{St}$ & $\mathrm{Al}$ & $\mathrm{Rs}$ & $\mathrm{Cg}$ & $\mathrm{S}$ \\
\hline Ethanol & + & + & + & - & - & + & + & + \\
Dichloromethane & - & + & + & - & + & + & + & - \\
Hexane & + & + & + & - & + & + & + & + \\
\hline
\end{tabular}

Key: $+=$ present,$-=$ not present $\mathrm{T}=$ Tannins, $\mathrm{F}=$ flavonoids, $\mathrm{Aq}=$ Anthraquinones, $\mathrm{St}=$ Steroids, $\mathrm{Al}=$ Alkaloids, $\mathrm{Rs}=$ Reducing sugars, $\mathrm{Cg}=$ Cardiac glycosides, $\mathrm{S}=$ saponins.

The percentage occurrence of MDR in the test bacterial isolates is shown in table 3. A total of 203 clinical isolates of both Gram positive and Gram negative bacteria were obtained from Aminu Kano Teaching Hospital. Out of the 203 isolates screened for MDR, 6 were confirmed as MDR with overall percentage of $10.48 \%$. This was however lower than finding of Ezeonu et al., 2007 who reported $39.2 \%$ prevalence. The highest percentage of MDR occurrence were found in $P$. aeruginosa with $(5.71 \%)$ followed by $S$. aureus with $(2.47 \%)$ while $K$. pneumoniae had $2.30 \%$. This variation could be due to sample size, local antibiotics and prescribing habits which differs from state to state, institution to institution.

Table 3: Occurrence of MDR among bacterial isolates

\begin{tabular}{lcc}
\hline Isolates & Number of sample screened & Number (\%) of MDR Isolates \\
\hline P. aeruginosa & 35 & $2(5.71)$ \\
S. aureus & 81 & $2(2.47)$ \\
K. pneumoniae & 87 & $2(2.30)$ \\
Total & $\mathbf{2 0 3}$ & $\mathbf{6 ( 1 0 . 4 8 )}$ \\
\hline
\end{tabular}

The antibacterial activity of $C$. verum bark extract against some microorganism was shown in table 4. In general, the sensitivity test results showed that all Cinnamomum verum extracts were active against the test isolates when compared with the sensitivity of the isolates to standard Ciprofloxacin $5 \mu \mathrm{g}$ disc. The ethanolic extract activity was higher in Gram negative isolates ( $P$. aeruginosa $12.3 \pm 0.5 \mathrm{~mm})$ and $K$. pneumoniae $(15.3 \pm 1.3 \mathrm{~mm})$ than Gram positive isolates. While hexane extract activity was higher in Gram positive $S$. aureus (15. $0 \pm 0.0 \mathrm{~mm}$ ) than Gram negative all at $100 \mathrm{mg} / \mathrm{ml}$. The results obtained in this study agreed with the findings of Keskin and Toroglu (2011), Ahuja et al., (2015) and Ahmed et al., (2020).

The variation in the sensitivity of different isolates tested to the extracts may also be as a result of the differences in the type of Gene responsible for their multi-drug resistance harbored by these organisms since there were more than 200 different phenotypes identified worldwide (Jacoby and Muno-Price, 2005). The antibacterial activity exhibited by the extracts may be associated with the presence of alkaloids, saponins and tannins in addition to flavonoids which was reported to be responsible for antimicrobial properties of some ethno medicinal plants (Singh and Bhat, 2003). The mechanism of activity of flavonoids include their ability to complex with extracellular and soluble proteins and to complex with bacterial cell walls as well as the ability of lipophilic flavonoids to disrupt microbial membranes (Tsuciya et al, 1996), that of alkaloids is attributed to their ability to intercalate with bacterial DNA (Phillipson and O'Neill, 1987), that of saponins has the ability to form pores in membranes hence exerting a bactericidal effect (Mujahid et al., 2017) while that of tannins may be related to their ability to inactivate microbial adhesions, enzymes, cell envelope transport proteins and the ability to complex with polysaccharides (Ya et al, 1988).

Table 4: Antibacterial activity of $C$. verum extracts against MDR isolates

\begin{tabular}{|c|c|c|c|c|c|c|c|}
\hline \multirow[t]{2}{*}{ Extracts } & 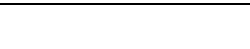 & \multicolumn{5}{|c|}{ Concentration $(\mathrm{mg} / \mathrm{ml})$ Zone of Inhibition $(\mathrm{mm})$} & \multirow{2}{*}{$\begin{array}{l}\text { Control } \\
\text { CPX } 10 \mu \mathrm{g}\end{array}$} \\
\hline & MDR Isolates & 100 & 80 & 60 & 40 & 20 & \\
\hline & $P$. aeruginosa & $12.3 \pm 0.5$ & $11.5 \pm 0.3$ & $11.3 \pm 0.5$ & $10.5 \pm 0.3$ & $9.0 \pm 0.4$ & 23 \\
\hline \multirow[t]{3}{*}{1} & K. pneumoniae & $15.3 \pm 1.3$ & $13.3 \pm 0.5$ & $12.8 \pm 0.5$ & $11.8 \pm 0.5$ & $11.3 \pm 0.5$ & 28 \\
\hline & S. aureus & $12.5 \pm 1.5$ & $11.0 \pm 0.0$ & $10.0 \pm 0.0$ & $9.0 \pm 0.0$ & $8.0 \pm 0.0$ & 25 \\
\hline & $P$. aeruginosa & $10.0 \pm 0.7$ & $9.0 \pm 0.4$ & $8.3 \pm 0.3$ & $8.0 \pm 0.4$ & $8.0 \pm 0.0$ & 23 \\
\hline \multirow[t]{3}{*}{2} & K. pneumoniae & $12.3 \pm 0.8$ & $9.5 \pm 0.5$ & $8.8 \pm 0.3$ & $8.8 \pm 0.3$ & $8.3 \pm 0.3$ & 28 \\
\hline & S. aureus & $11.5 \pm 1.5$ & $10.5 \pm 0.5$ & $10.0 \pm 1.0$ & $10.0 \pm 1.0$ & $8.5 \pm 0.5$ & 25 \\
\hline & $P$. aeruginosa & $10.5 \pm 0.9$ & $10.0 \pm 0.7$ & $9.3 \pm 0.9$ & $9.0 \pm 0.9$ & $8.3 \pm 0.3$ & 23 \\
\hline \multirow[t]{2}{*}{3} & K. pneumoniae & $14.5 \pm 0.5$ & $10.0 \pm 0.0$ & $9.0 \pm 0.7$ & $9.5 \pm 0.6$ & $8.8 \pm 0.3$ & 28 \\
\hline & S. aureus & $15.0 \pm 0.0$ & $11.5 \pm 0.5$ & $11.0 \pm 1.0$ & $9.5 \pm 0.5$ & $9.0 \pm 0.0$ & 25 \\
\hline
\end{tabular}

Key: CPX = Ciprofloxacin, 1 = Ethanol, 2 = Dichloromethane, $3-n-$ Hexane 
BAJOPAS Volume 14 Number 1, June, 2021

The minimum inhibitory concentrations of the extracts of $C$. verum shown in Table 5, ranged from 5 to $20 \mathrm{mg} / \mathrm{ml}$. Ethanol extracts of $C$. verum showed MIC at $10 \mathrm{mg} / \mathrm{ml}$ for $P$. aeruginosa and $S$. aureus and $20 \mathrm{mg} / \mathrm{ml}$ for $K$. pneumoniae, while dichloromethane extracts showed MIC at 20 $\mathrm{mg} / \mathrm{ml}$ for $P$. aureus and $K$. pneumoniae while $S$. aureus showed MIC at $5 \mathrm{mg} / \mathrm{ml}$. Hexane extract of C. verum showed MIC at $20 \mathrm{mg} / \mathrm{ml}$ for $K$. pneumoniae, $10 \mathrm{mg} / \mathrm{ml}$ for Pseudomonas aeruginosa and $5 \mathrm{mg} / \mathrm{ml}$ for Staphylococcus aureus.

The results of minimum bactericidal concentrations (MBC) test of $C$. verum bark ranged from 10 to $40 \mathrm{mg} / \mathrm{ml}$ as shown in table 6 . Ethanol extracts of $C$. verum showed MBC at 20 $\mathrm{mg} / \mathrm{ml}$ for $P$. aeruginosa and $S$. aureus isolates while $K$. pneumoniae showed $40 \mathrm{mg} / \mathrm{ml}$.
Dichloromethane extracts showed MBC at 40 $\mathrm{mg} / \mathrm{ml}$ for $P$. aeruginosa and $K$. pneumoniae while $S$. aureus showed $10 \mathrm{mg} / \mathrm{ml}$. Hexane extract showed $\mathrm{MBC}$ at $40 \mathrm{mg} / \mathrm{ml}$ for $K$. pneumoniae, 20 $\mathrm{mg} / \mathrm{ml}$ for $P$. aeruginosa and $10 \mathrm{mg} / \mathrm{ml}$ for $S$. aureus. There was also no growth on the control plate containing Ciprofloxacin.

Ethanol extract had higher MIC and MBC values on all the isolates compared to hexane extract while dichloromethane extract had the highest MIC and MBC $(20-40 \mathrm{mg} / \mathrm{ml})$ on all the isolates except against $S$. aureus. In this study the MIC values were lower than MBC values. This suggest that all the extracts were bactericidal at higher concentration and bacteriostatic at lower concentration. In 2012, Seanego and Ndip also reported similar finding in extracts of Garcinia kola seeds.

Table 5: Minimum Inhibitory Concentration of extract against tested MDR isolates

\begin{tabular}{llll}
\hline Isolates & \multicolumn{3}{c}{ Minimum Inhibitory Concentration $\mathbf{( m g / m l )}$} \\
& Ethanol & Dichloromethane & n-Hexane \\
\hline P. aeruginosa & 10 & 20 & 10 \\
K. pneumoniae & 20 & 20 & 20 \\
S. aureus & 10 & 5 & 5 \\
\hline
\end{tabular}

Table 6: Minimum Bactericidal Concentration of extract against tested MDR isolates

\begin{tabular}{llll}
\hline Isolates & \multicolumn{2}{l}{ Minimum Bactericidal Concentration $\mathbf{( m g / m l )}$} \\
& Ethanol & Dichloromethane & n-Hexane \\
\hline P. aeruginosa & 20 & 40 & 20 \\
K. pneumoniae & 40 & 40 & 20 \\
S. aureus & 20 & 10 & 10 \\
\hline
\end{tabular}

\section{CONCLUSION}

In this study the extraction of $C$. verum bark using different solvents indicated that there is variation in physical properties, plant secondary metabolites and antibacterial properties. The variation is however attributed to the polarity index of the solvent used. The highest yield was observed in ethanolic extract and the phytochemical screening of $C$. verum bark extract revealed that the plant is rich in secondary metabolites including; tannins, flavonoids, anthraquinones, steroids, alkaloids, reducing sugars, cardiac glycosides and saponins. Out of 203 isolated organisms, 35 were $P$. aeruginosa, 87 were $K$. pneumoniae and 81 were $S$. aureus. $K$. pneumoniae was the most sensitive of all the bacterial isolates tested. Out of the 203 isolates screened for MDR, 6 were confirmed as MDR with

\section{REFERENCES}

Ahmed H.M, Ashraf M.R., Ibrahim Y.E, Omer A.I. and Mohamed B.S. (2020). Phytochemical Screening, Chemical Composition and Antimicrobial Activity of Cinnamon verum Bark. International Research Journal of Pure \& Applied Chemistry, 21(11): 36-43 overall percentage of $10.48 \%$. The extracts have bacteriostatic at low and bactericidal at high concentrations and could compete favourably with Ciprofloxacin used even though they were in crude form thus the plant has potential for the production of drug for the treatment of infections caused by the MDR pathogens.

\section{RECOMMENDATIONS}

In view of the results obtained in this work, it is recommended that researchers should;

1. Isolate and identify the active compound(s) present in the extracts and fractions.

2. Determine the toxicity level of both crude extract and the active compound(s).

3. Further clinical evaluation of the effectiveness of C. verum species in in-vivo experiment is recommended.

Ahuja S., Dharmadikari M. and Joshi S. (2015). Phytochemical Screening and Antimicrobial activity of Cinnamon spice against Urinary tract Infection and Fungal pathogens. International Journal of Life Science and Pharma Research vol 5 
BAJOPAS Volume 14 Number 1, June, 2021

Aiyelaagbe O., and Osamudiamen P.M. (2009). Phytochemical Screening for Active Compounds in Mangifera indica Leaves from Ibadan Oyo State, Plant Sciences Research, 2(1):11-13.

Alabi A.S, Frielinghaus L, Kaba H. (2013). Retrospective analysis of antimicrobial resistance and bacterial spectrum of infection in Gabon, central Africa. BMC Infect Dis.13:455. doi:10.1186/14712334-13-455

Brain K.R. and Turner, T.D. (1975). The practical evaluation of phytochemicals. Wright Scientechina, Bristol: $57-58$.

Ciulci I. (1994). Methodology for the analysis of vegetable drugs. Chemical industries branch, Division of industrial operations. UNIDO, Romania: 24, 26 and 67.

CLSI (2012). Guidelines for Antimicrobial Susceptibility Testing, Clinical Laboratory Science Institute.

Cowan M. M. (1999). Plant products as antimicrobial agents. Clinical microbiology review 12(4): 564-582.

De La Torres J.E., Gassara F., Kouassi A.P., Brar S.K. and Belkacemi K. (2015). Spice use in Food: Properties and benefits. Critical Reviews in Food Science and Nutrition. 57 (6): 1078 - 1088

Dylan W. Petersona, Roshni C Georgea, Francesca Scaramozzino, Nichole E LaPointe, Richard A Anderson, Donald J Graves and John Lew (2009). J Alzheimer's disease 17: 585-597.

Jacoby G.A. and Muno-Price, L. S. (2005). The new beta-lactamases. New Engl. Journal. Med. 352: 380-391

John L., Ogle G.D., Scianna J Winslow S and Holzworth K. (2003). Plant Material Collection guide. $4^{\text {th }}$ edition USAID, Inc. New York.

Keskin D. and Toroglu, S. (2011). Studies on Antimicrobial activities of solvent extracts of different spices. J. Environ. Biol., 32. 251-256

Khandelwal K. R. (2008). Practical Pharmacognosis, Pragati books Pvt. Ltd.

Klein E.Y., Sun L., Smith D.L., Laxminarayan R. (2013).The changing epidemiology of methicillin-resistant Staphylococcus aureus in the United States: a national observational study. $A m \mathrm{~J}$ Epidemiol. 177:666-674

Kuta, F.A., Damisa, D., Adabara, N.U., Bello, I.M and Samuel S. (2012). Antibacterial activity of

Aloe vera plant extract on Salmonella typhi. Techno Science Africana Journal, 6(1): 83-86
Madiha I.Y., Rukayadi Y. and Norhayati H. (2017). Effects of extraction conditions on yield, total

phenolic contents and antibacterial activity of methanolic Cinnamomum zeylanicum blume leaves extract. International Food Research Journal. 24(2): 779-786

Mannaa D., Mandal A.K., and Sen I.K. (2015). Antibacterial and DNA degradation potential of

silver nanoparticles synthesized via green route. Int $\mathrm{J}$ Biol Macromol. 80:455-459. doi:10.1016/j. ijbiomac.2015.07.028

Mazimba O., Wale K., Tebogo E., Tebogo E., Kwape S.O. (2015). Cinnamomum verum: Ethylacetate and methanol extracts antioxidant and antimicrobial activity. J Med Plants Studies. 3(3):28-32.

Meena V., Sree S.N., Surya- Prakash D.V. and Sumanjali A. (2012). A Review on Pharmacological Activities and Clinical effects of Cinnamon Species. Research Journal of Pharmaceutical, Biological and Chemical Sciences. 20:121-129

Miyashita M. and Sadzuka Y. (2013). Effect of Linalool as a component of Human lupulus on Doxorubicin-induced antitumor activity. Food and Chemical Toxicology. 53: 174-179

Mujahid N.S., Kutama A.S., Sani N.M. and Bashir A. (2017). In-vitro Antifungal evaluation of Cinnamomum zylanicum and Leptodenia hostata on Malassezia species. UMYU Journal of Microbiology Research. 2(1): 251-256

Mustafa Z. O. and Hilal, K., (2004). "Super-heated water extraction steam distillation and soxhlet extraction of essential oil of Origanum onites". Anal Bioanal Chem. 379:1127-1133.

Nurjadi D. Friedrich-Jänicke B., Schäfer J. (2015). Skin and soft tissue infections in intercontinental travelers and the import of multi-resistant Staphylococcus aureus to Europe. Clin Microbiol Infect. 21:567e1-10. doi:10.1016/j.cmi.2015.01.016

Oke O. A. (2000). Phytotherapy in pregnancy; In crosscutting issue in Ethics, Law and Medicine. Emiric O.F. Africa center of Law and human concern: 49-50.

Phillipson J. D. and O'Neill M. J. (1987). New leads to the treatment of protozoal infections based on natural product molecules. Acta Pharm. Nord. 1: 131-144

Prestinaci F., Perzzotti P. and Pantosti A. (2015). Antimicrobial resistance: A global multifaceted phenomenon. Pathog Glob Health. 109: 309-318 
BAJOPAS Volume 14 Number 1, June, 2021

Rezaie M., Farhoosh, R., Iranshahi, M., Sharif A. and Golmohamadzadeh, S. (2015). Ultrasonic-assisted extraction of antioxidative compounds from Bene (Pistacia atlantica subsp. Mutica) hull using various solvents of different physicochemical properties. Food Chemistry 173: 577-83

Sarker D.S., Latif Z. and Gray A.L. (2006). Natural Products isolation, $2^{\text {nd }}$ edition. Humana Press Inc; ISBN 1588294471. Pp 323

Seanego C. T. and Ndip R. N. (2012). Identification and antibacterial evaluation of bioactive compounds from Garcinia kola (Heckel) seeds. Molecules 17(6): 6569-6584

Sheng L. and Zhu M.J. (2014). Inhibitory effect of Cinnamomum cassia oil on non-0157 Shiga toxin-producing Escherichia coli. Food Control. 46; 374-381

Singh B. and Bhat T. K. (2003). Potential therapeutic applications of some antinutritional plant secondary metabolites. Journal. Agric. Food Chem. 51:5579-5597.

Sofowora A. (1993): Medicinal plants and Traditional Medicines in Africa. Chichester John Wiley \& Sons New York. Pp. 34-36.

Sofowora A, Ogunbodede E, Onayade A. (2013). The Role and Place of Medicinal Plants in the Strategies for Disease Prevention.
African Journal of Traditional, Complementary and Alternative Medicines 10(5):210-229.

Tapsell L. C. Hemphill, I. and Cobiac, L. (2006). Health benefit of herbs and spices: the past, the present, the future. Medical Journal Australia, 185:24-54.

Tschehe R. (1971). Advances in the chemistry of antibiotic substances from higher plants: Pharmacognosy and phytochemistry. In proceeding of $1^{\text {st }}$ International Congress, Munich, 1970: 274-289.

Tsuciya H., Sato, M., Miyazaki, T., Fujiwara, S., Tanigaki, S., Ohyama, M., Tanaka, T. and Iinuma, M. (1996). Comparative study on the antibacterial activity of phytochemical flavones against methicillin-resistant Staphylococcus aureus. Journal Ethnopharmacol. 50: 27-34.

Ya C., Gaffney, S. H., Lilley, T. H. and Haslam, E. (1988). Carbohydrate polyphenol complexation, In Hemingway, R. W. and Karchesy, J. J. (ed.), Chemistry and significance of condensed tannins. Plenum press New York. P553.

Yusha'u M., Aliyu H., Kumurya A. and Suleiman K. (2010). Prevalence of extended spectrum $\beta$-lactamases (ESBLs) among Enterobacteriaceae in Murtala Muhammad Specialist Hospital, Kano, Nigeria. Bayero Journal of Pure and Applied Sciences, 3 (1): 169-172 